\title{
KONTRIBUSI LIMBAH CAIR PASAR FLAMBOYAN TERHADAP KUALITAS AIR DI PARIT TOKAYA KOTA PONTIANAK

\author{
Zulfika Yunita ${ }^{1)}$ Johnny MTS $^{2)}$ Laili Fitria $^{1)}$
} \\ ${ }^{1)}$ Program Studi Teknik Lingkungan Jurusan Teknik Sipil Fakultas Teknik Universitas Tanjungpura, Pontianak \\ 2) Program Studi Teknik Sipil Jurusan Teknik Sipil Fakultas Teknik Universitas Tanjungpura, Pontianak Email : fika.yzulfika@gmail.com
}

\begin{abstract}
ABSTRAK
Parit Tokaya merupakan saluran yang digunakan untuk menampung buangan dan sekaligus air hujan. Salah satu aktivitas yang berada di sekitar Parit Tokaya yakni aktivitas di Pasar Flamboyan. Pasar flamboyant sudah memiliki pengolahan limbah di bagian Pasar Sayur dan sebagian Pasar Daging dan Ayam, namun khusus Pasar Ikan belum termasuk bagian pengolahan tersebut. Penelitian ini bertujuan untuk melihat kontribusi atau pengaruh dari Pasar Flamboyan terhadap kualitas air di Parit Tokaya, trend sebaran pencemar domestik dan rata - rata beban pencemaran di Parit Tokaya. Penelitian diawali dengan pengambilan sampel secara grab sample pada saat pasang dan surut, mengukur kecepatan air, luas penampang, debit dan analisis kualitas air. Besarnya kontribusi Pasar Flamboyan dilihat berdasarkan beberapa pendekatan, yakni dari penurunan kualitas air berdasarkan trend sebaran, luas wilayah dan persentase penurunan konsentrasi buangan. Kontribusi Pasar Flamboyan hanya terukur dalam bentuk persentase dan belum memberikan nilai yang sesungguhnya. Hasil analisis menunjukkan bahwat trend sebaran parameter pencemar saat pasang cenderung meningkat dari arah hilir ke hulu dan saat surut terjadi sebaliknya. Kontribusi limbah cair Pasar Flamboyan terbesar untuk setiap parameter yakni sebesar $83,31 \%$ pada saat pasang dan $15,62 \%$ pada saat surut untuk parameter BOD, untuk parameter amonia sebesar $54,68 \%$ saat pasang dan $19,89 \%$ saat surut, untuk parameter nitrit sebesar $62,86 \%$ saat pasang dan $100 \%$ saat surut, untuk parameter nitrat sebesar $60,35 \%$ saat pasang dan $33,33 \%$ saat surut, sedangkan untuk parameter TSS sebesar $70,9 \%$ saat pasang dan $10,32 \%$ saat surut. Rata - rata beban pencemar Parit Tokaya pada saat pasang cenderung lebih besar daripada saat terjadinya surut, kecuali parameter BOD dan Amoniak. Rata - rata beban pencemar Parit Tokaya untuk parameter BOD sebesar 35,8 $\mathrm{kg} / \mathrm{hari}$ (pasang) dan 348,72 kg/hari (surut), parameter TSS sebesar 904,22 kg/hari (pasang) dan 235,10 kg/hari (surut), parameter amonia sebesar 14,67 kg/hari (pasang) dan 166,71 kg/hari (surut), parameter nitrat sebesar $34,70 \mathrm{~kg} / \mathrm{hari}$ (pasang) dan 2,24 kg/hari (surut), parameter nitrit sebesar 0,16 kg/hari (pasang) dan 0,03 kg/hari (surut).
\end{abstract}

Kata Kunci : Air Buangan, Pasar Flamboyan, Parit Tokaya, Kontribusi

\begin{abstract}
Tokaya trench is a channel used to accommodate the rain water and discharge at the same time. One of the activities which around of Tokaya Trench is the Flamboyan Market. Before then Flamboyan Market already have sewage treatment for two parts of the market, those are the Vegetable Market and Chicken Meat Market, but especially Fish Market has not been included in the processing section. This study aims to look at the contribution or influence of Flamboyan Market on the quality of water in Tokaya Trench, domestic contaminant distribution trend and the average of pollution load in Tokaya Trench. The study has begun by grab sample sampling at the time of high tide and low tide, measuring the water velocity, cross-sectional area, discharge and water quality analysis. The contribution of Flamboyan Market has seen by several approaches, they are decline of the water quality based on the distribution trend, area and percentage of reduction in effluent concentrations. Contribution of Flamboyan Market only measured in terms of percentage and yet provide real value. The analysis showed a trend that the distribution of pollutant parameters when the tide is likely to increase from downstream to upstream and downs when the opposite occurs. Contribution of Flamboyan Market wastewater which is the biggest for every parameter is equal to $83.31 \%$ at high tide and at low tide $15.62 \%$ for the BOD parameter, ammonia parameter amounted to $54.68 \%$ at high tide and $19.89 \%$ at low tide, to the parameters nitrites by $62.86 \%$ at high tide and $100 \%$ at low tide, for the nitrate parameter is $60.35 \%$ at high tide and $33.33 \%$ at low tide, while the parameter of TSS is $70.9 \%$ at high tide and $10.32 \%$ at low tide. The Average of the pollutant load in Tokaya Trench at high tide tends to be greater than the time of low tide, except the parameters of BOD and Ammonia. The average of pollutant load of BOD parameter in Tokaya Trench is $35.8 \mathrm{~kg} /$ day (high tide) and $348.72 \mathrm{~kg} /$ day (low tide), parameter of TSS is $904.22 \mathrm{~kg} /$ day (high tide) and $235.10 \mathrm{~kg} /$ day (low tide), ammonia parameter $14.67 \mathrm{~kg} /$ day (high tide) and $166.71 \mathrm{~kg} /$ day (low tide),
\end{abstract}


nitrate parameter is $34.70 \mathrm{~kg} /$ day (high tide) and $2.24 \mathrm{~kg} /$ day (low tide), nitrite parameter is $0.16 \mathrm{~kg} /$ day (high tide) and $0.03 \mathrm{~kg} /$ day (at low tide).

Keyword : Waste Water, Flamboyan Market, Tokaya Trench, Contribution

\section{A. PENDAhuluan}

Pasar Flamboyan merupakan pasar tradisional yang terletak di kawasan pemukiman padat, dan berlokasi tepat di pinggiran Parit Tokaya. Parit tersebut digunakan masyarakat setempat untuk keperluan MCK, namun buangan pasar langsung dibuang ke Parit tersebut. Parit Tokaya merupakan salah satu anak Sungai Kapuas yang terletak di Kecamatan Pontianak Selatan. Panjang Parit Tokaya yakni sebesar $\pm 6,7 \mathrm{~km}$ (BPS, 2014). Sebelumnya, pemerintah setempat telah menyediakan pengolahan air buangan di Pasar Flamboyan, namun belum semua air buangan yang berasal dari Pasar masuk dalam pengolahan. Pasar Flamboyan terbagi menjadi tiga bagian yakni, Pasar daging dan ayam, Pasar Sayur dan Pasar Ikan, khusus Pasar Ikan belum termasuk dalam cakupan pengolahan air buangan. Adanya penurunan kualitas air di Parit Tokaya menjadikan Pasar Flamboyan dianggap sebagai penyebab utama timbulnya penyakit gatal - gatal terjadi, oleh masyarakat setempat (Greeners, 2012). Selain itu, sesuai hasil pemeriksaan kualitas air yang dilakukan oleh Badan Lingkungan Hidup (BLH) Pontianak tahun 2014, kualitas air di sekitar kawasan Pasar Flamboyan telah terjadi penurunan berdasarkan PP 82 Tahun 2001. Berdasarkan alasan - alasan tersebut maka dilakukan penelitian untuk mengetahui besarnya kontribusi atau pengaruh limbah cair pasar Flamboyan terhadap kualitas air di kawasan tersebut, bagaimana sebaran pencemaran limbah domestik yang terjadi, dan rata - rata beban pencemar di Parit Tokaya.

\section{B. METODOLOGI PENELITIAN}

\section{- LOKASI DAN WAKTU PENELITIAN}

Penelitian dilakukan di Parit Tokaya dan kawasan Pasar Flamboyan, Kecamatan Pontianak Selatan, Kota Pontianak, Provinsi Kalimantan Barat. Pengambilan data berlangsung selama 5 bulan, yakni dari bulan Maret - Agustus 2015. Lokasi penelitian terdiri dari 12 titik, 10 titik yang terletak di Parit Tokaya (T1, T2, T3, T4, T5, T6, T7, T8, T9, dan T10) yang dipilih berdasarkan pertimbangan penggunaan lahan dan kemudahan dalam pengambilan sampel, 2 titik lainnya terletak di outlet buangan dari Pasar Flamboyan (4A dan 5A). Berikut ini merupakan lokasi pengambilan sampel :

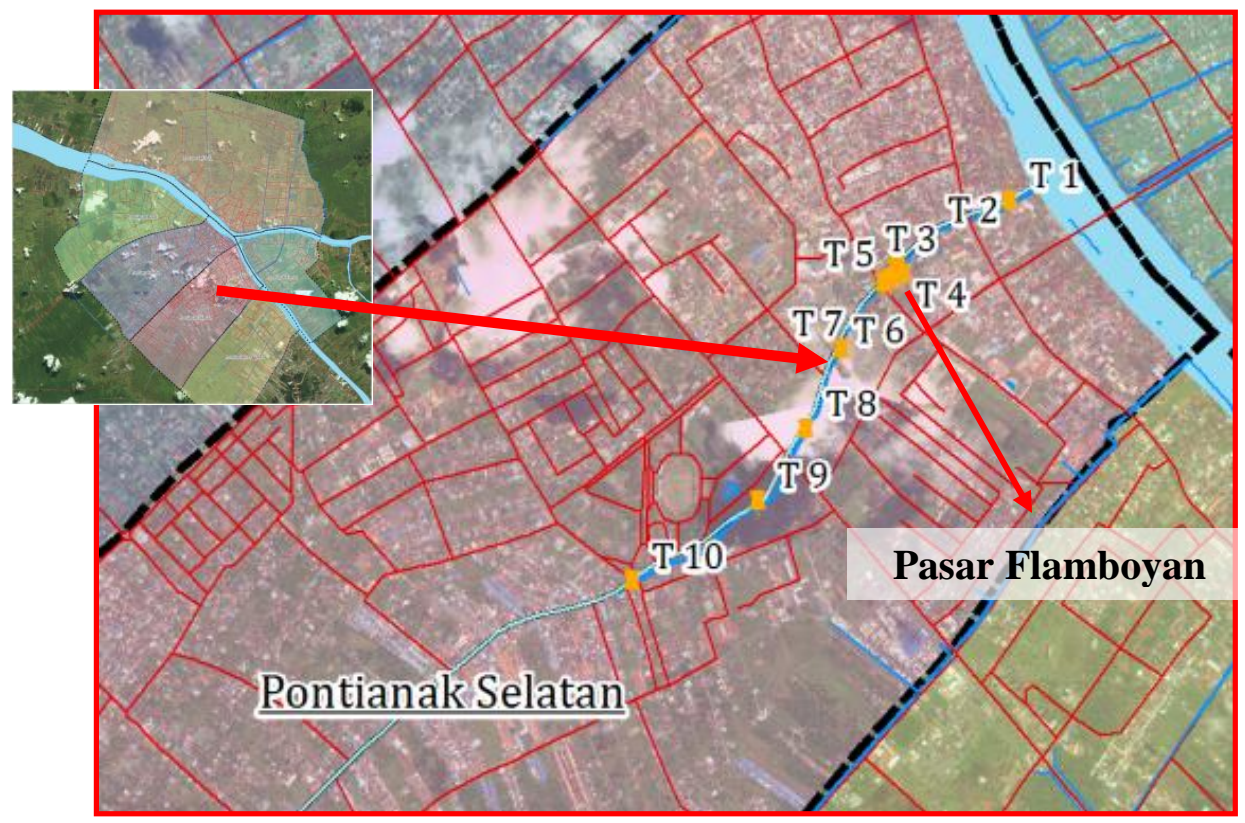

Gambar 1. Lokasi Penelitian 


\section{- $\quad$ ALAT DAN BAHAN}

Alat dan bahan yang digunakan pada penelitian ini yaitu rambu ukur untuk mengukur kedalaman parit, GPS (Global Positioning System) yang digunakan untuk menentukan titik pengambilan sampel, pita ukur yang digunakan untuk mengukur lebar parit, stopwatch untuk mengukur waktu, botol sampel, termometer yang berfungsi untuk mengukur suhu sampel, pelampung untuk mengukur kecepatan, cooling box sebagai wadah pengawetan sampel, dan alat tulis.

\section{- PROSEDUR PENELITIAN}

Pengambilan sampel dilakukan sebanyak 2 kali dengan menggunakan cara grab sample untuk setiap titik berdasarkan waktu saat terjadinya pasang dan surut, yakni pada jam 17.00 WIB waktu terjadinya pasang dan jam 07.00 WIB waktu terjadinya surut. Pengambilan sampel air permukaan dilakukan pada kedalaman $0,5 \mathrm{~h}$ dari permukaan perairan pada waktu yang bersamaan. Sampel yang telah diambil selanjutnya dianalisis di laboratorium PT Superintending Company Of Indonesia (SUCOFINDO) dan Laboratorium Kualitas dan Kesehatan Lahan, Fakultas Pertanian Universitas Tanjungpura.

\section{- $\quad$ ANALISIS DATA}

Analisis data dilakukan dengan beberapa data pendukung dari beberapa instansi terkait. Analisis data meliputi kualitas air, rata - rata beban pencemaran saat terjadinya pasang dan surut dan trend sebaran parameter limbah cair domestik. Peraturan yang digunakan dalam menganalisis konsentrasi kualitas air buangan yang berasal dari Parit Tokaya terdapat dua peraturan yakni PP no. 82 tahun 2001 saat pasang dan PerMenLH no. 5 tahun 2014 saat surut, hal ini dikarenakan pada saat pasang saluran buangan ikut terendam oleh air yang berasal dari Parit Tokaya, sedangkan saat surut, saluran buangan tidak dipengaruhi oleh aliran air di Parit Tokaya dikarenakan muka air yang dangkal. Kontribusi Pasar Flamboyan dilihat berdasarkan persentase perubahan konsentrasi setiap paramater dari outlet saluran ke perairan di Parit Tokaya. Berikut merupakan beberapa persamaan yang digunakan untuk mendukung analisis sampel :

Perhitungan debit menggunakan persamaan :

$$
Q=A . v
$$

Sumber : Siringo-ringo, 2014

Dengan, $Q \quad$ : Debit $\left(\mathrm{m}^{3} / \mathrm{dtk}\right)$

A : Luas penampang basah saluran $\left(\mathrm{m}^{2}\right)$

$v \quad:$ Kecepatan arus $(\mathrm{m} / \mathrm{dtk})$

Perhitungan rata - rata konsentrasi dalam satu saluran menggunakan persamaan :

$$
C_{R}=\frac{\sum C i . Q i}{\sum Q i}=\frac{\sum M i}{\sum Q i} \text {. }
$$

Sumber : KepmenLH No. 110, 2003

Dengan, $C_{R} \quad$ : Konsentrasi rata - rata konstituen untuk aliran gabungan $(\mathrm{mg} / \mathrm{l})$

$\mathrm{C}_{\mathrm{i}} \quad$ : Konsentrasi konstituen pada aliran ke-i $(\mathrm{mg} / \mathrm{l})$

$\mathrm{Q}_{\mathrm{i}} \quad$ : Laju alir aliran ke-i (l/dtk)

$\mathrm{M}_{\mathrm{i}} \quad$ : Massa konstituen pada aliran ke-i

Beban pencemar dihitung dengan menggunakan persamaan :

$$
B P=C_{R} \cdot Q \cdot f \text {. }
$$

Sumber : Siringo-ringo, 2014

Dengan, $\mathrm{BP} \quad$ : Beban pencemar $(\mathrm{kg} / \mathrm{hari})$

$C_{R} \quad$ : Konsentrasi rata - rata pencemar $(\mathrm{mg} / \mathrm{l})$

Q : Debit $\left(\mathrm{m}^{3} /\right.$ hari)

f : Faktor konversi $=\frac{1 \mathrm{~kg}}{1.000 .000 \mathrm{mg}} \times \frac{1000 \mathrm{~L}}{1 \mathrm{~m}^{3}}=0,001$ 
Persentase perubahan konsentrasi pencemar dihitung berdasarkan efisiensi penurunan konsentrasi pencemar di sumber setelah memasuki perairan, sehingga persamaan yang digunakan yakni persamaan efisiensi pada umumnya, berikut persamaan tersebut :

$$
\% \text { Perubahan konsentrasi }=\frac{\text { K.B.Pasar }- \text { K.Perairan }}{\text { K.B.Pasar }} \times 100 \% \text {. }
$$

Dengan, K.B Pasar : : Konsentrasi buangan pasar (mg/l)

K. Perairan : Konsentrasi di perairan $(\mathrm{mg} / \mathrm{l})$

\section{HASIL DAN PEMBAHASAN}

\section{- TREND SEBARAN PARAMETER LIMBAH CAIR DOMESTIK}

- Biochemical Oxygen Demand (BOD)

Konsentrasi BOD di setiap titik pada saat pasang memiliki kecenderungan meningkat dari hilir ke hulu. Nilai konsentrasi BOD sangat bergantung pada kadar oksigen terlarut di dalam air, namun berbanding terbalik. Hal ini telah dijelaskan sebelumnya bahwa peningkatan nilai BOD diiringi dengan menurunnya nilai oksigen terlarut di perairan (Sitanggang, 2013). Proses terjadinya pasang menyebabkan arus air bergerak dari arah hilir ke hulu, sedangkan pada saat surut terjadi sebaliknya. Hal tersebut dapat dilihat pada gambar 2 berikut ini :
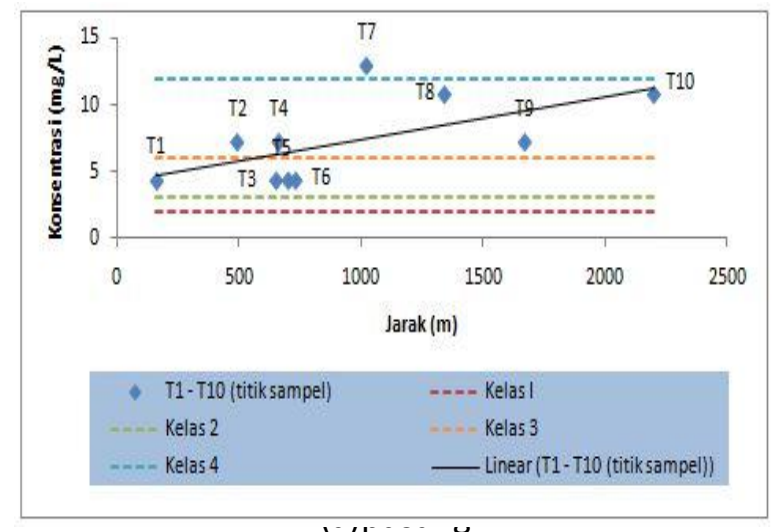

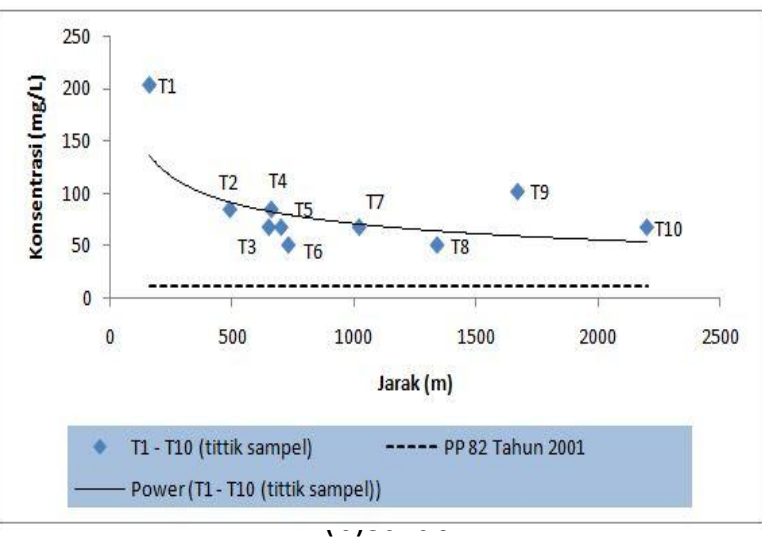

Gambar 2. BOD saat Pasang dan Surut

Trend sebaran BOD yang pada gambar 2 tersebut menunjukkan bahwa peningkatan BOD yang terjadi mengikuti bentuk trend sebaran linear pada saat pasang, sedangkan trend sebaran BOD pada saat surut menggunakan pendekatan dengan bentuk trend sebaran power. Nilai konsentrasi BOD yang berada di kawasan Pasar Flamboyan yakni titik 3, 4, 5 dan 6 cukup bervariasi pada saat pasang dan surut. Titik 3 merupakan titik di hilir pasar Flamboyan yang berarti bahwa kualitas air belum dipengaruhi oleh limbah Pasar Flamboyan pada saat pasang. Titik 4 dan 5 merupakan titik yang berada di depan saluran buangan limbah Pasar Flamboyan, dan titik 6 merupakan titik hulu dari kawasan Pasar Flamboyan. Hasil pengukuran dari ke empat titik tersebut menunjukkan bahwa nilai BOD tertinggi terletak pada titik 4 pada saat pasang, dimana lokasi titik tersebut merupakan titik yang berada di depan saluran buangan pasar Flamboyan yakni titik sampel 4A. Selengkapnya dapat dilihat pada tabel 2 berikut ini :

Tabel 2. Konsentrasi BOD dari Outlet Pasar

\section{(a)pasang}

\begin{tabular}{cccccc}
\hline & \multirow{3}{*}{ Lokasi } & $\begin{array}{c}\text { Baku Mutu Berdasarkan Peraturan } \\
\text { Uji }\end{array}$ & \multicolumn{3}{c}{ Pemerintah No. 82 Tahun 2001 } \\
\cline { 3 - 6 } & $(\mathbf{m g} / \mathbf{l})$ & Kelas & Kelas & Kelas & Kelas \\
& & I & II & III & IV \\
\hline $4 \mathrm{~A}$ & 45,71 & 2 & 3 & 6 & 12 \\
$5 \mathrm{~A}$ & 8,57 & $\mathrm{mg} / \mathrm{l}$ & $\mathrm{mg} / \mathrm{l}$ & $\mathrm{mg} / \mathrm{l}$ & $\mathrm{mg} / \mathrm{l}$ \\
\hline
\end{tabular}

(b)surut

\begin{tabular}{|c|c|c|c|}
\hline \multirow{2}{*}{ Lokasi } & \multirow{2}{*}{$\begin{array}{l}\text { Hasil Uji } \\
\text { (mg/I) }\end{array}$} & \multicolumn{2}{|c|}{$\begin{array}{c}\text { Baku Mutu Berdasarkan } \\
\text { PerMenLH No. } 5 \text { Tahun } 2014\end{array}$} \\
\hline & & Gol I & Gol II \\
\hline $4 \mathrm{~A}$ & 508,47 & 50 & 150 \\
\hline $5 \mathrm{~A}$ & 542,37 & mg/l & $\mathrm{mg} / \mathrm{l}$ \\
\hline
\end{tabular}

Kualitas air di titik 4 yang berada didepan saluran buangan pasar tidak dipengaruhi secara langsung oleh buangan pasar, hal ini dikarenakan titik $4 \mathrm{~A}$ pada saat pasang langsung terendam oleh volume air yang meningkat, sehingga sampel di titik 4 (didepan saluran buangan Pasar) memiliki konsentrasi 
yang lebih kecil. Oleh karena adanya pengenceran terlebih dahulu di saluran buangan Pasar, maka peraturan yang digunakan pun mengikuti kualitas air permukaan sesuai dengan PP 82 tahun 2001. Konsentrasi BOD saat pasang di saluran buangan Pasar Flamboyan di titik 4A lebih besar dibandingkan dengan titik $5 \mathrm{~A}$, hal ini dikarenakan adanya perbedaan aktivitas yang menyumbang langsung limbah ke saluran tersebut.

Titik 4A merupakan titik dimana kegiatan Pasar terdiri dari penjual daging sapi, ayam dan ikan, sedangkan titik $5 A$ hanya mengalirkan limbah yang berasal dari Pasar Ikan. Sebaliknya, saat surut konsentrasi BOD di titik $4 \mathrm{~A}$ lebih kecil dibandingkan dengan titik $5 \mathrm{~A}$, dikarenakan waktu pengambilan sampel saat pasang pada jam 17.00 WIB dan saat surut pada jam 07.00 WIB.

\section{- $\quad$ Amonia $\left(\mathrm{NH}_{3}\right.$ sebagai $\left.\mathrm{N}\right)$}

Trend sebaran parameter amonia di perairan dipengaruhi oleh buangan limbah yang masuk, kecepatan oksidasi dalam siklus nitrogen, serta waktu dan kondisi saat pengambilan sampel. Berikut merupakan sebaran parameter amonia saat kondisi pasang dan surut :

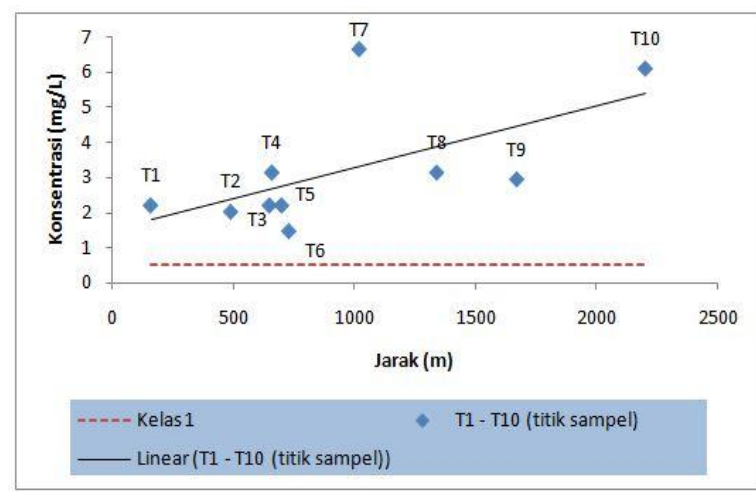

(a)pasang

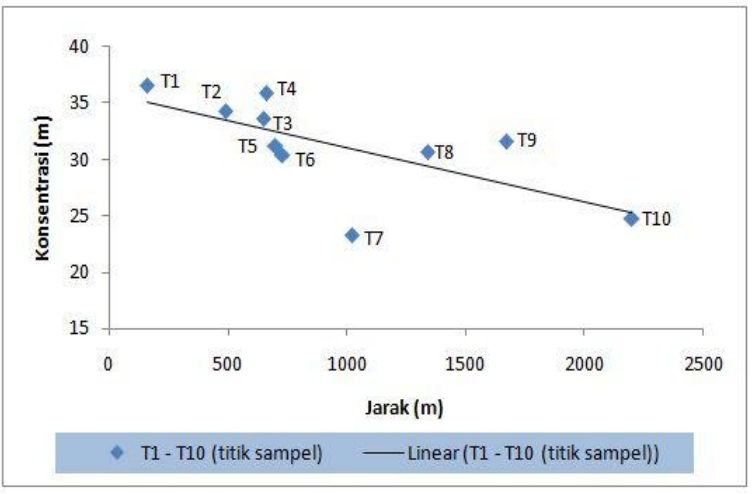

(b)surut

Gambar 3. Trend Sebaran BOD saat Pasang dan Surut

Saat keadaan aerob, amonia akan teroksidasi menjadi nitrit dan nitrat, sehingga konsentrasi amonia di dalam perairan juga mempengaruhi besar kecilnya konsentrasi nitrat maupun nitrit yang ada (Aswadi, 2012). Trend sebaran amonia yang cenderung menurun saat terjadinya surut disebabkan oleh karena tingginya konsentrasi BOD saat terjadinya surut. Intensitas membuang limbah saat terjadinya surut (jam 07.00 WIB) cenderung lebih besar dibanding saat terjadinya pasang (jam 17.00 WIB) (Sasongko, 2006), sehingga konsentrasi BOD lebih besar, terlebih lagi volume air saat surut lebih sedikit dibandingkan saat terjadinya pasang. Menurut Effendi (2003), konsentrasi amonia sebanding dengan laju dekomposisi pencemar yang terdapat dalam perairan. Diketahui bahwa pada saat surut pun, konsentrasi BOD juga semakin menurun ke arah hulu. Hal ini berlaku pula pada saat pasang, seperti pada gambar 3. Berikut merupakan konsentrasi amonia di outlet buangan pasar saat pasang dan surut :

Tabel 3. Konsentrasi Amonia dari Outlet Pasar

\begin{tabular}{cccccc}
\multicolumn{8}{c}{ (a)pasang } \\
\hline \multirow{3}{*}{ Lokasi } & Hasil & \multicolumn{4}{c}{ Baku Mutu Berdasarkan Peraturan } \\
& $\begin{array}{c}\text { Uji } \\
\text { (mg/I) }\end{array}$ & Kelas & Kelas & Kelas & Kelas \\
& & I & II & III & IV \\
\hline 4A & 15,49 & 0,5 & - & - & - \\
5A & 2,03 & $\mathrm{mg} / \mathrm{l}$ & $\mathrm{mg} / \mathrm{l}$ & $\mathrm{mg} / \mathrm{I}$ & $\mathrm{mg} / \mathrm{l}$ \\
\hline
\end{tabular}

\begin{tabular}{|c|c|c|c|}
\hline \multirow{2}{*}{ Lokasi } & \multirow{2}{*}{$\begin{array}{l}\text { Hasil Uji } \\
\text { (mg/l) }\end{array}$} & \multicolumn{2}{|c|}{$\begin{array}{l}\text { Baku Mutu Berdasarkan } \\
\text { PerMenLH No. } 5 \text { Tahun } 2014\end{array}$} \\
\hline & & Gol I & Gol II \\
\hline $4 \mathrm{~A}$ & 324 & 5 & 10 \\
\hline $5 \mathrm{~A}$ & 180,5 & $\mathrm{mg} / \mathrm{l}$ & $\mathrm{mg} / \mathrm{l}$ \\
\hline
\end{tabular}

Titik $5 \mathrm{~A}$, tidak memberikan pengaruh yang cukup besar terhadap konsentrasi amonia di titik 5 (di depan saluran buangan 5A). Konsentrasi amonia di titik $5 \mathrm{~A}$ lebih sedikit dibanding $4 \mathrm{~A}$ dikarenakan kegiatan di 4A (pasar ikan) lebih besar dibandingkan di 5A (pasar daging dan ayam, dan sebagian dari pasar ikan), sehingga saat memasuki Parit akan lebih sedikit lagi karena akan mengalami pengenceran pula. Penyebab lain yang menghasilkan konsentrasi amonia di titik hilir cenderung tetap, dapat disebabkan oleh adanya pengurangan aktivitas bakteri dalam hal 
mengoksidasi amonia menjadi nitrit dan nitrat (Nugroho, 2005). Kecenderungan yang menurun ini juga terjadi saat berada di kawasan Pasar. Titik 3, 4, 5 dan 6 yang merupakan kawasan Pasar Flamboyan juga memiliki konsentrasi amonia yang cenderung menurun hingga di titik 7 pada saat surut, terkecuali saat pasang hanya sampai titik 6 .

\section{- $\quad$ Nitrite $\left(\mathrm{NO}_{2}\right.$ sebagai $\left.\mathrm{N}\right)$}

Berikut merupakan trend sebaran parameter nitrit saat pasang dan surut di Parit Tokaya :

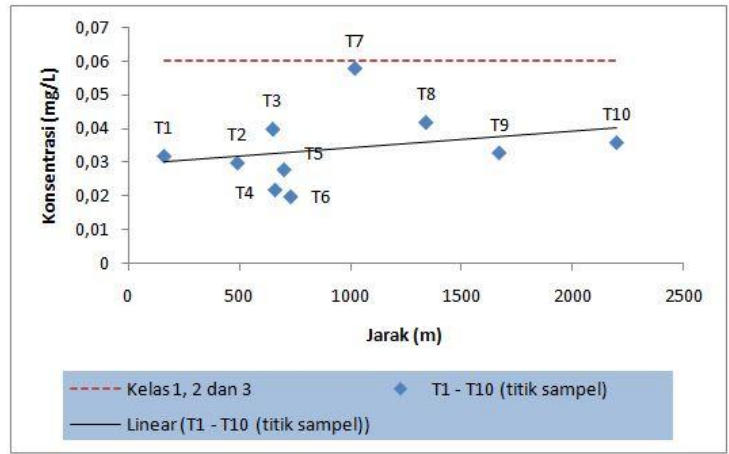

(a)pasang

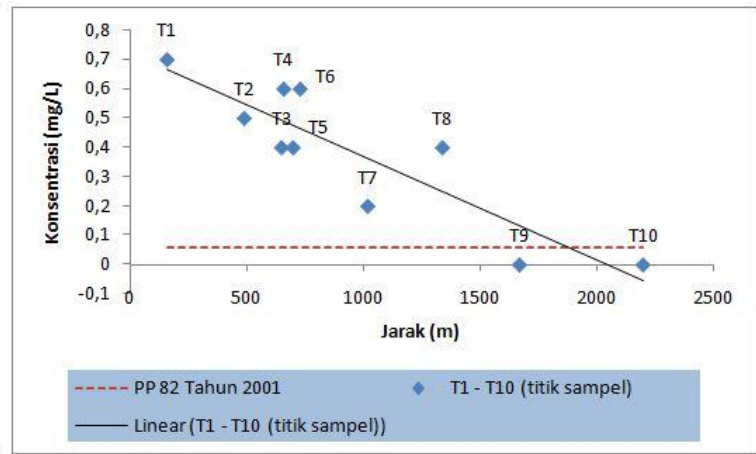

(b)surut

Gambar 4. Trend Sebaran Nitrit saat Pasang dan Surut

Konsentrasi nitrit di sekitar kawasan Pasar Flamboyan yakni titik 3 hingga titik 6, memiliki konsentrasi nitrit yang cenderung turun saat pasang maupun surut. Titik 3 mengalami peningkatan konsentrasi nitrit menjadi $0,04 \mathrm{mg} / \mathrm{l}$ kemudian setelah memasuki kawasan Pasar Flamboyan konsentrasi nitrit menjadi semakin kecil hingga titik 6 saat pasang. Hal ini terjadi karena disebabkan oleh kondisi aliran yang pasang membuat konsentrasi nitrit menjadi terencerkan meskipun nitrit di sumber pencemar melebihi batas baku mutu Peraturan Pemerintah No. 82 tahun 2001. Berikut merupakan tabel 4 konsentrasi nitrit saat pasang dan surut :

Tabel 4. Konsentrasi Nitrit dari Outlet Pasar

(a)pasang

\begin{tabular}{cccccc}
\hline \multirow{2}{*}{ Lokasi } & $\begin{array}{c}\text { Hasil } \\
\text { Uji }\end{array}$ & \multicolumn{4}{c}{ Baku Mutu Berdasarkan Peraturan } \\
\cline { 3 - 6 } & $(\mathbf{m g} / \mathbf{l})$ & $\begin{array}{c}\text { Kelas } \\
\text { I }\end{array}$ & $\begin{array}{c}\text { Kelas } \\
\text { II }\end{array}$ & $\begin{array}{c}\text { Kelas } \\
\text { III }\end{array}$ & $\begin{array}{c}\text { Kelas } \\
\text { IV }\end{array}$ \\
\hline 4A & 1,458 & 0,06 & 0,06 & 0,06 & - \\
$5 \mathrm{~A}$ & 0,035 & $\mathrm{mg} / \mathrm{l}$ & $\mathrm{mg} / \mathrm{I}$ & $\mathrm{mg} / \mathrm{l}$ & $\mathrm{mg} / \mathrm{l}$ \\
\hline
\end{tabular}

(b)surut

\begin{tabular}{cccc}
\hline & & \multicolumn{2}{c}{ Baku Mutu Berdasarkan } \\
Lokasi & $\begin{array}{c}\text { Hasil Uji } \\
(\mathbf{m g} / \mathrm{l})\end{array}$ & \multicolumn{2}{c}{ PerMenLH No. 5 Tahun 2014 } \\
\cline { 3 - 4 } & & Gol I & Gol II \\
\hline $4 \mathrm{~A}$ & 0 & 1 & 3 \\
$5 \mathrm{~A}$ & 0,019 & $\mathrm{mg} / \mathrm{l}$ & $\mathrm{mg} / \mathrm{l}$ \\
\hline
\end{tabular}

Konsentrasi nitrit yang rendah disebabkan karena amonia yang masih tinggi di sumber buangan, sehingga membuktikan bahwa oksidasi amonia tidak berjalan maksimal. Konsentrasi amonia yang terkecil berada di titik $4 \mathrm{~A}$, dimana dititik tersebut merupakan titik dengan nilai amonia tertinggi diantara keduanya.

\section{- $\quad$ Nitrate $\left(\mathrm{NO}_{3}\right.$ sebagai $\left.\mathrm{N}\right)$}

Berikut merupakan trend sebaran parameter nitrat saat pasang dan surut :

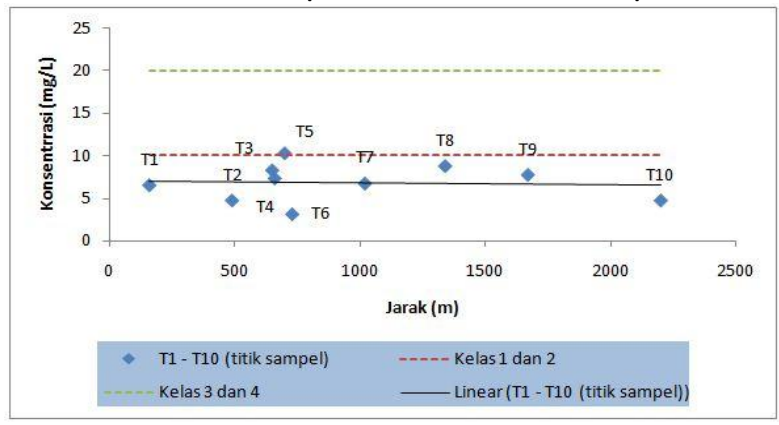

(a)pasang

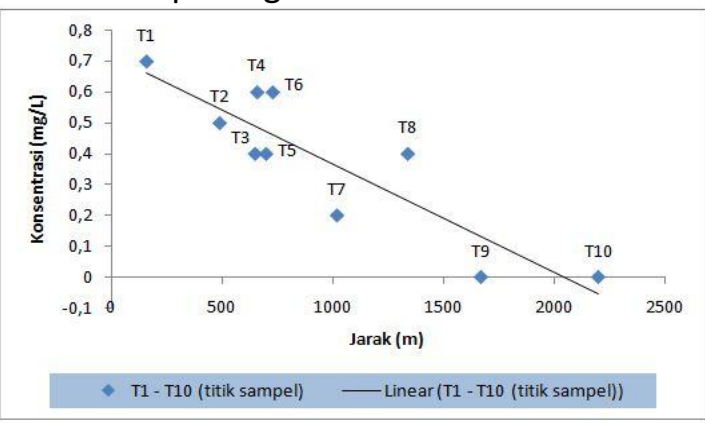

(b)surut

Gambar 5. Trend Sebaran Nitrat saat Pasang dan Surut 
Trend sebaran nitrat pada penelitian ini terlihat bahwa konsentrasi nitrat dari hilir ke hulu cenderung datar saat terjadinya pasang. Berdasarkan hal tersebut maka dapat diketahui bahwa nitrat hampir tersebar merata di sepanjang Parit Tokaya. Tersebar meratanya nitrat pada gambar menjelaskan bahwa adanya perbedaan oksidasi nitrit menjadi nitrat ataupun nitrat menjadi nitrogen, yang dipengaruhi oleh sejumlah buangan yang masuk pada saat pengambilan sampel. Trend sebaran saat surut mendekati bentuk grafik linear. Nitrat saat surut cenderung lebih rendah daripada saat terjadinya pasang. Berikut merupakan tabel konsentrasi nitrat di Pasar Flamboyan :

Tabel 5. Konsentrasi Nitrat dari Outlet Pasar

(a)pasang

\begin{tabular}{|c|c|c|c|c|c|}
\hline \multirow{2}{*}{ Lokasi } & \multirow{2}{*}{$\begin{array}{c}\text { Hasil } \\
\text { Uji } \\
(\mathrm{mg} / \mathrm{l})\end{array}$} & \multicolumn{4}{|c|}{$\begin{array}{c}\text { Baku Mutu Berdasarkan Peraturan } \\
\text { Pemerintah No. } 82 \text { Tahun } 2001\end{array}$} \\
\hline & & $\begin{array}{c}\text { Kelas } \\
\text { I }\end{array}$ & $\begin{array}{c}\text { Kelas } \\
\text { II }\end{array}$ & $\begin{array}{c}\text { Kelas } \\
\text { III }\end{array}$ & $\begin{array}{l}\text { Kelas } \\
\text { IV }\end{array}$ \\
\hline $4 \mathrm{~A}$ & 18,58 & 10 & 10 & 20 & 20 \\
\hline $5 A$ & 4,59 & $\mathrm{mg} / \mathrm{l}$ & $\mathrm{mg} / \mathrm{l}$ & $\mathrm{mg} / \mathrm{l}$ & $\mathrm{mg} / \mathrm{l}$ \\
\hline
\end{tabular}

(b)surut

\begin{tabular}{cccc}
\hline \multirow{2}{*}{ Lokasi } & $\begin{array}{c}\text { Hasil Uji } \\
(\mathbf{m g} / \mathrm{l})\end{array}$ & \multicolumn{2}{c}{$\begin{array}{c}\text { Baku Mutu Berdasarkan } \\
\text { PerMenLH No. 5 Tahun 2014 }\end{array}$} \\
\cline { 3 - 4 } & & Gol I & Gol II \\
\hline $4 \mathrm{~A}$ & 0,3 & 20 & 30 \\
$5 \mathrm{~A}$ & 6,2 & $\mathrm{mg} / \mathrm{l}$ & $\mathrm{mg} / \mathrm{l}$ \\
\hline
\end{tabular}

Saat berada di saluran buangan waktu pasang, limbah di titik hulu lebih kecil dibandingkan di titik hilir, sedangkan saat berada di perairan limbah di titik hulu menjadi lebih besar di titik. Ketika aliran pasang, air mengalir dari hilir ke hulu, sehingga menyebabkan beban nitrat di titik 5 semakin besar karena konsentrasi nitrat di titik 4 telah terakumulasi. Saat surut nitrat yang berada di titik $5 \mathrm{~A}$ lebih tinggi dibandingkan dengan nitrat yang berada di titik 4A. Hal ini terjadi oleh karena nitrat lebih banyak dihasilkan oleh aktivitas Pasar Ikan.

\section{- $\quad$ Total Suspended Solid (TSS)}

Konsentrasi TSS pada saat pasang dipengaruhi oleh pola aliran air pada saat pasang pula. Ketika pasang, aliran air menuju hulu sehingga konsentrasi TSS di muara akan lebih kecil dibandingkan dengan hulu Parit, karena suspensi bahan organik yang terakumulasi di titik tersebut. Berikut merupakan gambar 6 yang menunjukkan trend sebaran TSS saat pasang dan surut :

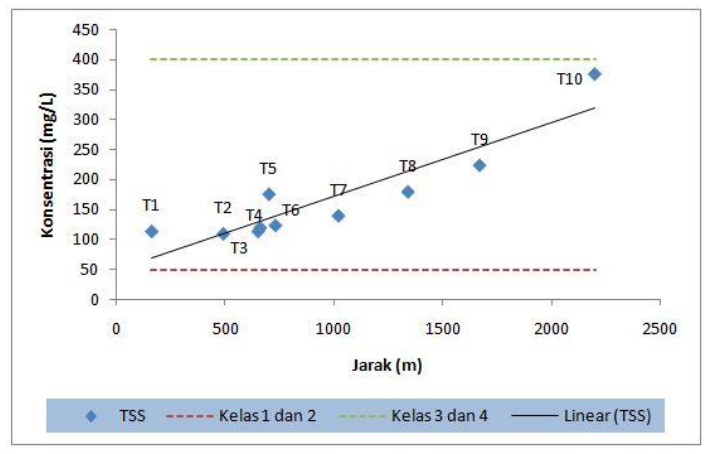

(a)pasang

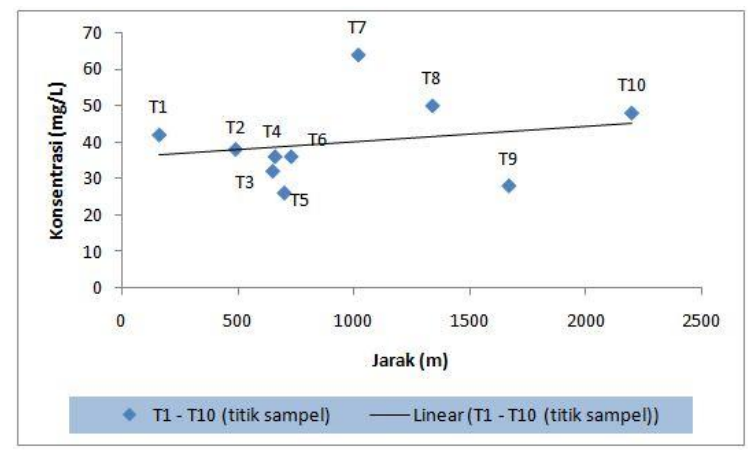

(b)surut

Gambar 6. Trend Sebaran TSS saat Pasang dan Surut

TSS yang masuk ke dalam Parit akan mengalami pengadukan dan pencampuran, namun oleh karena adanya akumulasi dengan konsentrasi TSS di titik sebelumnya sehingga menyebabkan konsentrasi TSS di titik 3 hingga 5 cenderung naik. Saat di titik 6, konsentrasi TSS kembali menurun, hal ini dapat terjadi oleh karena Parit sudah mampu melakukan pemulihan kualitas air secara alami, dan mengindikasikan bahwa suspensi yang terlarut telah mulai mengendap saat pasang. Trend sebaran TSS saat surut dari hilir ke hulu akan semakin meningkat, dengan mendekati bentuk grafik linear. Hal ini dikarenakan aktivitas di hulu sudah semakin sedikit dibandingkan di hilir. Proses dekomposisi di titik hulu juga lebih rendah daripada di hilir, hal ini terlihat di parameter BOD sebelumnya. Berikut merupakan konsentrasi TSS di outlet pasar : 
(a)pasang

\begin{tabular}{|c|c|c|c|c|c|}
\hline \multirow{2}{*}{ Lokasi } & \multirow{2}{*}{$\begin{array}{c}\text { Hasil } \\
\text { Uji } \\
\text { (mg/l) }\end{array}$} & \multicolumn{4}{|c|}{$\begin{array}{l}\text { Baku Mutu Berdasarkan Peraturan } \\
\text { Pemerintah No. } 82 \text { Tahun } 2001\end{array}$} \\
\hline & & $\begin{array}{c}\text { Kelas } \\
\text { I }\end{array}$ & $\begin{array}{c}\text { Kelas } \\
\text { II }\end{array}$ & $\begin{array}{c}\text { Kelas } \\
\text { III }\end{array}$ & $\begin{array}{l}\text { Kelas } \\
\text { IV }\end{array}$ \\
\hline $4 \mathrm{~A}$ & 470 & 50 & 50 & 400 & 400 \\
\hline $5 A$ & 170 & $\mathrm{mg} / \mathrm{l}$ & $\mathrm{mg} / \mathrm{l}$ & $\mathrm{mg} / \mathrm{l}$ & $\mathrm{mg} / \mathrm{l}$ \\
\hline
\end{tabular}

(b)surut

\begin{tabular}{|c|c|c|c|}
\hline \multirow{2}{*}{ Lokasi } & \multirow{2}{*}{$\begin{array}{l}\text { Hasil Uji } \\
(\mathrm{mg} / \mathrm{l})\end{array}$} & \multicolumn{2}{|c|}{$\begin{array}{l}\text { Baku Mutu Berdasarkan } \\
\text { PerMenLH No. } 5 \text { Tahun } 2014\end{array}$} \\
\hline & & Gol I & Gol II \\
\hline $4 \mathrm{~A}$ & 310 & 200 & 400 \\
\hline $5 \mathrm{~A}$ & 450 & $\mathrm{mg} / \mathrm{l}$ & $\mathrm{mg} / \mathrm{l}$ \\
\hline
\end{tabular}

Titik 4 dan 5 berada tepat di saluran buangan Pasar Flamboyan, dengan konsentrasi TSS di saluran buangan $4 \mathrm{~A}$ lebih tinggi dibandingkan dengan $5 \mathrm{~A}$, menyebabkan trend sebaran saat pasang meningkat. Konsentrasi TSS yang berada di sumber saat surut, tidak memiliki perbedaan nilai yang cukup jauh dibandingkan saat terjadinya pasang. Titik 5A yang merupakan titik hilir, memiliki konsentrasi TSS yang lebih besar dibandingkan dengan titik 4A dikarenakan Pasar Ikan menghasilkan buangan padat maupun cair yang lebih besar dibanding Pasar daging dan ayam yang hanya membuang limbah cair seperti air rebusan atau pun limbah darah di saluran buangan tersebut.

Suhu $\left({ }^{\circ} \mathrm{C}\right)$

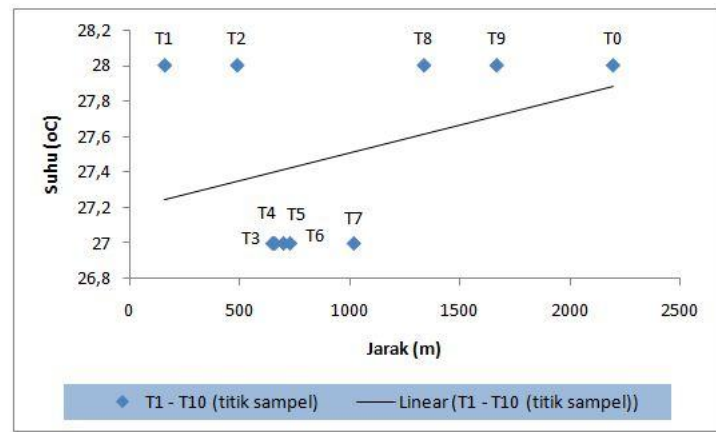

(a)pasang

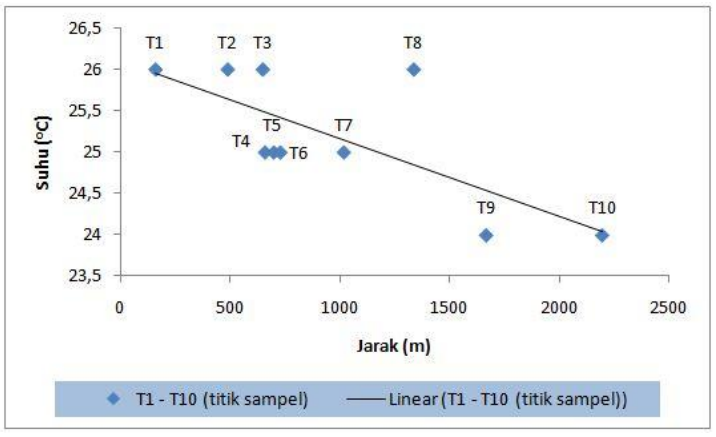

(b)surut

Gambar 7. Trend Sebaran Suhu saat Pasang dan Surut

Meningkatnya suhu di titik hulu, disebabkan oleh aktivitas bakteri yang meningkat dikarenakan beban limbah yang besar di hulu. Menurut Effendi (2003), peningkatan suhu menyebabkan peningkatan kecepatan metabolisme dan respirasi organisme air, dan selanjutnya meningkatkan konsumsi oksigen. Saat surut, diketahui bahwa perubahan suhu dari arah hilir ke hulu mengalami penurunan seiring dengan bertambahnya jarak. Sampel air pada saat surut terjadi pada jam 07.00 WIB, sedangkan pasang 17.00 WIB. Suhu di perairan membutuhkan waktu yang lebih lama untuk menaikkan dan menurunkan suhu, jika dibandingkan daratan (Jeffries dan Mills (1996) dalam Effendi (2003)). Hal ini menjelaskan bahwa pada saat surut, suhu air dipengaruhi oleh kondisi pada waktu sebelumnya yakni pada malam hari dimana suhu pada waktu tersebut relatif rendah, begitu pula pada saat terjadinya pasang.

\section{- RATA - RATA BEBAN PENCEMAR DAN KONTRIBUSI AIR BUANGAN PASAR FLAMBOYAN}

Berikut merupakan rata - rata beban pencemar di Parit Tokaya pada saat pasang dan surut :

Tabel 8. Rata - rata Beban Pencemar saat Pasang dan Surut

\begin{tabular}{ccccc}
\hline \multirow{2}{*}{ Parameter } & \multicolumn{2}{c}{$\begin{array}{c}\text { Rata - rata Beban Pencemar } \\
\text { ( } \mathbf{k g} / \text { hari) }\end{array}$} & \multicolumn{2}{c}{$\begin{array}{c}\text { Debit Rata - rata } \\
\left(\mathbf{m}^{\mathbf{3}} / \text { hari) }\right.\end{array}$} \\
\cline { 2 - 5 } & Pasang & Surut & Pasang & Surut \\
\hline BOD & 35,48 & 348,72 & & \\
TSS & 904,22 & 235,10 & & \\
Amonia & 14,67 & 166,71 & 5304,72 & 15938,41 \\
Nitrat & 34,70 & 2,24 & & \\
Nitrit & 0,16 & 0,03 & & \\
\hline
\end{tabular}

Tingginya beban pencemar yang berasal dari TSS pada saat pasang dapat berasal dari berbagai macam aktivitas di daratan yang memasuki perairan ataupun erosi di dinding saluran 
(Effendi, 2003). Konsentrasi BOD yang tinggi pada saat terjadinya surut menunjukkan bahwa pengenceran yang dilakukan tidak berlangsung maksimal dibandingkan dengan konsentrasi limbah yang masuk. Menurut Putri (2007) proses pasang surut mempengaruhi bahan pencemar dalam suatu perairan dikarenakan adanya pencampuran (mixing) dan pengadukan (turbulence).

Analisis luas lahan pada penelitian ini dilakukan dengan membatasi luas area yang dianggap berkontribusi langsung ke Parit Tokaya, yakni dengan jarak 0,89 km dari Parit Tokaya. Jarak ini merupakan jarak fasilitas yang berada di dalamnya memberikan kontribusi langsung ke Parit Tokaya. Luas wilayah keseluruhan yakni sebesar $3,13 \mathrm{~km}^{2}$, dengan luas pemukiman sebesar $2,82 \mathrm{~km}^{2}$, Pasar Flamboyan sebesar $0,028 \mathrm{~km}^{2}$ dan Gedung Olahraga sebesar $0,28 \mathrm{~km}^{2}$. Luas Pasar Flamboyan yang hanya sebesar $0,028 \mathrm{~km}^{2}$ lebih kecil dibandingkan dengan luas pemukiman keseluruhan, yakni sebesar $2,85 \mathrm{~km}^{2}$. Hal ini menunjukkan bahwa kontribusi limbah yang lebih besar yang berasal dari pemukiman dibandingkan dengan kontribusi Pasar Flamboyan terhadap Parit Tokaya. Kontribusi limbah cair Pasar Flamboyan diambil berdasarkan persentase perubahan konsentrasi limbah setelah memasuki perairan. Hal ini dikarenakan sudah terwakilinya gambaran adanya kontribusi Pasar dari 4 titik di sekitar Pasar Flamboyan. 4 titik sampel tersebut yakni titik 3, 4, 5, dan 6. Berikut tabel 9 perubahan konsentrasi saat pasang :

Tabel 9. \%Penurunan Konsentrasi Air Buangan Pasar Flamboyan saat Pasang

\begin{tabular}{cccccc}
\hline Lokasi & BOD\% & TSS\% & Amonia\% & Nitrit\% & Nitrat\% \\
\hline Saluran 4A & 90,64 & 75,74 & 85,73 & 97,26 & 55,25 \\
Saluran 5A & 16,69 & 29,41 & $\begin{array}{c}54,68 \text { (tidak efisien } \\
\text { terencerkan) }\end{array}$ & 37,14 & $\begin{array}{c}\text { 60,35 (tidak efisien } \\
\text { terencerkan) }\end{array}$ \\
\hline
\end{tabular}

Persentase penurunan tertinggi konsentrasi buangan Pasar setelah memasuki badan air pada saat pasang yakni terdapat pada parameter nitrit dengan persentase penurunannya sebesar 97,26\%. Persentase penurunan konsentrasi Nitrit ini menunjukkan bahwa nitrit yang berasal dari saluran telah berada dalam kondisi yang semakin berkurang oleh karena volume air yang bertambah yang mengindikasikan adanya penambahan oksigen, sehingga menyebabkan konsentrasi nitrit menjadi tidak stabil (Effendi, 2003).

Tabel 10. \%Penurunan Konsentrasi Air Buangan Pasar Flamboyan saat Surut

\begin{tabular}{|c|c|c|c|c|c|}
\hline Lokasi & BOD\% & TSS\% & Amonia\% & Nitrit\% & Nitrat\% \\
\hline Saluran $4 \mathrm{~A}$ & 86,67 & 89,68 & 89,63 & 0,00 & $\begin{array}{c}\text { 33,33 (tidak efisien } \\
\text { terencerkan) }\end{array}$ \\
\hline Saluran $5 A$ & 84,38 & 92,00 & 80,11 & 73,68 & 90,32 \\
\hline
\end{tabular}

Saat surut konsentrasi penurunan terbesar terjadi pada parameter TSS dengan persentase sebesar 92\%. TSS dipengaruhi oleh beberapa macam aktivitas yang menghasilkan suspensi terlarut didalam air seperti penggerusan dinding saluran, penyaringan, dan sebagainya. Persentase perubahan konsentrasi tersebut menunjukkan bahwa kualitas buangan Pasar sudah mampu terencerkan sebanyak sekian persen berdasarkan konsentrasi setiap parameter yang terukur. Sisa dari total $100 \%$ pengenceran merupakan nilai kontribusi buangan Pasar yang terukur, sehingga jika \%penurunan BOD sebesar 90,64\% maka sisanya sebesar 9,36\% merupakan persentase buangan Pasar yang ikut terukur dari total konsentrasi di perairan yang berada di depan saluran buangan. Pasar Flamboyan hanya menyumbang 9,36\% konsentrasi pencemarnya ke Parit Tokaya dari total konsentrasi BOD di perairan tepatnya di depan buangan Pasar, nilai persentase kontribusi yang diambil merupakan persentase terbesar dari kedua saluran setelah pengurangan $100 \%$ dengan persentase perubahan konsentrasi. Khusus untuk konsentrasi yang terukur sesungguhnya belum dilakukan pada penelitian ini, hal ini dikarenakan konsentrasi buangan domestik yang berasal dari sumber lain tidak dilakukan pengujian kualitas buangan.

\section{KESIMPULAN}

Berdasarkan hasil analisis dan bahasan terhadap kualitas air di Parit Tokaya dan buangan Pasar Flamboyan, maka dapat disimpulkan beberapa hal yakni :

1. Trend sebaran limbah cair domestik di Parit Tokaya pada saat pasang cenderung mengalami kenaikan dari arah hilir ke hulu, sedangkan pada saat surut terjadi sebaliknya. 
2. Limbah cair Pasar Flamboyan yang berasal dari Pasar Ikan dapat menyebabkan penurunan kualitas air di sekitar kawasan Pasar. Namun berdasarkan bentuk trend sebaran yang ada, diketahui bahwa penggunaan lahan lain yang memberikan sumbangan terbesar dalam hal penurunan kualitas air yakni yang berasal dari pemukiman. Kontribusi limbah cair Pasar Flamboyan pada saat pasang dan surut yakni sebesar $83,31 \%$ pada saat pasang dan $15,62 \%$ pada saat surut untuk parameter BOD, untuk parameter ammonia sebesar $54,68 \%$ saat pasang dan $19,89 \%$ saat surut, untuk parameter nitrit sebesar $62,86 \%$ saat pasang dan $100 \%$ saat surut, untuk parameter nitrat sebesar $60,35 \%$ saat pasang dan $33,33 \%$ saat surut, sedangkan untuk parameter TSS sebesar $70,9 \%$ saat pasang dan $10,32 \%$ saat surut.

3. Beban pencemar di Parit Tokaya pada saat pasang lebih kecil dibandingkan saat surut, rata rata beban pencemaran Parit Tokaya pada saat pasang sebesar 35,48 kg/hari (BOD), 904,22 $\mathrm{kg} /$ hari (TSS), 14,67 kg/hari (Ammonia), 34,70 kg/hari (Nitrat), dan 0,16 kg/hari (Nitrit), sedangkan pada saat surut sebesar 348,72 kg/hari (BOD), 235,10 kg /hari (TSS), 166,71 kg/hari (Ammonia), 2,24 kg/hari (Nitrat) dan 0,03 kg/hari (Nitrit). Kualitas air di Parit Tokaya pada saat surut sudah melebihi batas baku mutu yang ditetapkan sesuai dengan PP 82 tahun 2001.

\section{UCAPAN TERIMA KASIH}

Penulis mengucapkan terima kasih yang sebesar - besarnya kepada bapak Dr. Ir Johnny MTS, M.Sc dan Ibu Laili Fitria, ST, MT selaku dosen pembimbing, Ibu Yulisa Fitrianingsih, ST, MT, dan Ibu Isna Apriani, ST, M.Si selaku dosen penguji, yang telah memberikan bimbingan, kritik, dan saran yang konstruktif demi menghasilkan penelitian yang baik.

\section{DAFTAR PUSTAKA}

Aswadi, Muhammad. 2012. Pemodelan Fluktuasi Nitrogen (Nitrit) Pada Aliran Sungai Pal. Jurnal Smartek.

Badan Pusat Statistik Kota Pontianak. 2014. Kecamatan Pontianak Selatan dalam Angka. Pontianak. Effendi, Hefni. 2003. Telaah Kualitas Air, Bagi Pengelolaan Sumber Daya dan Lingkungan Perairan. Yogyakarta. Kanisius.

Greeners. 2012. Limbah Pasar Flamboyan Ancam Kesehatan Warga. http://www.greeners.co/2012/limbah-pasar-flamboyan-ancam-kesehatan-warga. Diakses tanggal 31 Januari 2015.

Keputusan Menteri Lingkungan Hidup Nomor 110 Tahun 2003, Tentang Pedoman Penetapan Daya Tampung Beban Pencemaran Air Pada Sumber Air.

Nugroho, Rudi. 2005. Denitrifikasi Limbah Nitrat Pada Berbagai Tingkat Keasaman dengan Memanfaatkan Mikroba Autotroph. Pusat Pengkajian dan Penerapan Teknologi Lingkungan, BPPT.

Peraturan Pemerintah Republik Indonesia Nomor 82 Tahun 2001, Tentang Pengelolaan Kualitas Air dan Pengendalian Pencemaran Air.

Putri, Wike Ayu Eka. 2007. Kapasitas Asimilasi Bahan Pencemar Di Muara Sungai Batang Arau (Muara Padang), Sumatera Barat. Jurrnal Sumberdaya Perairan.

Sasongko, Lutfi Aris. 2006. Kontribusi Air Limbah Domestik Penduduk Di Sekitar Sungai Tuk Terhadap Kualitas Air Sungai Kaligarang Serta Upaya Penanganannya. Semarang. Universitas Diponegoro.

Siringo-ringo, Rosmasari. 2014. Kajian Beban Pencemaran Beberapa Anak Sungai dan Saluran Drainase yang Bermuara ke Sungai Kapuas di Kota Pontianak. Fakultas Teknik. Universitas Tanjungpura

Sitanggang, Eva Pramuni Oktaviani. 2013. Pola Sebaran Konsentrasi Oksigen Terlarut Pada Parit Tokaya. Fakultas Teknik. Universitas Tanjungpura.

Peraturan Menteri Lingkungan Hidup Republik Indonesia Nomor 5 Tahun 2014, Tentang Baku Mutu Air Limbah. 